DOI: https://doi.org/10.34069/AI/2021.46.10.27 How to Cite:

Chernysh, A., \& Horbolis, L. (2021). The ukrainian experience of national identity transformation (On the material "under the wings of big mother" by S. Protsiuk). Amazonia Investiga, 10(46), 273-280. https://doi.org/10.34069/AI/2021.46.10.27

\title{
The ukrainian experience of national identity transformation (On the material "under the wings of big mother" by S. Protsiuk)
}

\author{
Український досвід трансформації національної ідентичності \\ (на матеріалі роману С. Процюка «Під крилами великої Матері»)
}

Received: August 12, 2021

\author{
Received: August 12, 2021
}

Accepted: October 21, 2021

\begin{abstract}
This article is devoted to the investigation of Ukrainian national identity transformation, conditioned by the events of the Revolution of Dignity in the novel "Under the Wings of Big Mother" by S. Protsiuk. It was found out that the problem of national identity is the key one on the thematic, problematic, ideological, and figurative levels. The basic categories in the process of the new national identity formation in the novel "Under the Wings of Big Mother" by S. Protsiuk are pain, suffering, sorrow, and fear. The transformation of the national identity is subordinate to the moral and ethical discourse of changes, which were prompted by the revolution. The article serves to analyze political obstacles, mental traps and drawbacks of Ukrainian psychological character that prevented Ukrainians from forming a strong national identity. Changes of Ukrainian national identity is caused by the traumatic experience of Ukraine being a part of USSR, marked by genocide, linguicide, culturicide, Holodomor, and political repressions. The transformation of Ukrainian national identity in the beginning of the $21 \mathrm{st}$ century made possible the establishment of the key national identities (identitas): history, language, territory, basic national symbols and codes. It was proved that the modification of the national identity and the awareness of the ethnic value and self-identification are possible on the condition of understanding of mental traps and psychological drawbacks of Ukrainians that
\end{abstract}

Анотація

Стаття присвячена дослідженню трансформації національної ідентичності українців, зумовленої подіями Революції Гідності у романі С. Процюка «Під крилами великої Матері». 3'ясовано, що проблема національної ідентичності ключова на тематичному, проблемному, ідейному та образному рівнях. Базовими категоріями у процесі становлення нової національної ідентичності у романі С. Процюка «Під крилами великої Матері» є біль, страждання, скорбота, страх. Трансформація національної ідентичності підпорядкована моральноетичному дискурсу змін, що постали в результаті революції. У статті проаналізовано політичні перешкоди, ментальні пастки і вади психологічної вдачі українців, що заважали українському народу у формуванні міцної національної ідентичності. Зміни у національній ідентичності українців зумовлені травматичним досвідом перебування України у складі СРСР, позначеним геноцидом, лінгвоцидом, культуроцидом, Голодомором, політичними репресіями. Трансформація національної ідентичності українців на початку XXI ст. уможливила вкорінення ключових ідентитетів нації - історії, мови, території, базових національних символів i кодів. Доведено, що модифікація національної ідентичності й усвідомлення етнічної цінності й самототожності можлива за умови усвідомлення ментальних пасток i

\footnotetext{
${ }^{104} \mathrm{PhD}$ in Philology. Doctoral Student at National Pedagogical Dragomanov University (Kyiv, Ukraine).

${ }^{105}$ Dr. of Science in Philology. Professor of the Department of Ukrainian Language and Literature at Sumy State Pedagogical University (Sumy, Ukraine).
} 
impeded the Ukrainian people of forming their identity and world view to the full extent.

Key words: national identity, consciousness, fear, identity (identitas), mentality.

\section{Introduction}

Recently, Ukraine celebrated its 30th anniversary as a separate and independent country, certifying the uniqueness of its territory, language and history. For a long time, it has fought for the right to independence, gone the thorny way to develop and realize its national identity and self-esteem. During the years of independence in Ukraine, there were significant events that proved its ability to cope with the challenges of time and problems. The most notable of them were the Act of Independence of Ukraine, the All-Ukrainian referendum, the adoption of the Constitution of Ukraine, the Orange Revolution, the Revolution of Dignity, the defence of the territorial integrity of Ukraine, decommunization, etc. The most tragic of these events were the revolutionary events of 2004 and 2013-2014. and anti-terrorist operations and operations to defend Ukraine's territorial integrity. These events presented a unique reaction of the Ukrainian and world community, being reflected in a number of works of art, documentary and journalistic research, covering the discourse of tragedy, suffering, pain, and loss of the Ukrainian nation.

In Ukrainian literature, writers artistically formalized the events of the Revolution of Dignity (Euromaidan), the anti-terrorist operations and operations of the United Forces into the revolutionary and military discourse of the early XXI century. The most poignant were the works of S. Protsyuk "Under the wings of the Great Mother", V. Amelina "November Syndrome, or Homo Compatiens", V. Baziv "Armageddon on the Maidan", S. Bondarenko "Maidan and magnates", V. Medvid "Indestructible", A. Kokotiukha "Fire Earth", S. Pantyuk "War and We", I. Rozdobudko "Button-2", D. Savchenko "Pendulum of the Revolution", V. Shklyar "Black Sun", G. Vdovychenko "Mariupol process", Y. Polozhiy "Ilovaysk" V. Ivchenko "2014", S. Talan "Naked Nerve", G. Kyrpa "My Dad Became a Star", as well as publicist, journalistic, and documentary research and almanacs of O. Zabuzhko, V. Karpyuk, M. Matios, M. Slaboshpytskyi and others.

Revolutionary and military literature demonstratively models the themes of mental психологічних вад українців, що заважали повноцінному світоуявленню i світоставленню українства.

Ключові слова: національна ідентичність, свідомість, страх, ідентитет, ментальність.

crises and injuries of Ukrainians. Maidan concepts of 2004 and 2013-2014 became mental codes of the awareness of national identity and self-identity, emphasizing an aggravated sense of justice. This literature deprives of national infantilism, eradicating social and civil apathy, irresponsibility, passivity, insecurity. Ukrainian fiction about the events of the revolution contributes to the development of a new anticolonial philosophy of the national spirit without a sense of slavery, dependence, inferiority and uniformity. This literature basically forms the idea of the Maidan as a concept of justice and overcoming the fear of national oblivion. Therefore, it is extremely relevant for the formation of mentality and national identity, playing a significant role in the process of turning the crowd into a nation.

The novel "Under the Wings of Big Mother" (2015) by S. Protsiuk is characterized by poignant insight and the depth of subjective emotional experience of the events known as the Revolution of Dignity. The author's standpoint in this literary works clear and expressive, no matter how hard S. Protsiuk tried to hide himself behind the images of his characters. This is, perhaps, the only novel of the Ukrainian writer, in which Barthes' principle of "the death of the author" does not work, because the text reveals a topical for every conscious Ukrainian problem of regeneration, changes, and sometimes even reformation of Ukrainian consciousness and identity.

The problem of the national identity is the main one on the problematic and topical, ideological, figurative and even poetical levels of the novel organization. The artistic material, at first sight, is quite similar to the romantic model of text formation (differentiation between positive and negative characters (Maidan supporters and vatniks), love triangle (Lukash - Olesia - Viktor Ivanovych), exceptional circumstances, rebellious atmosphere, the opposition of a new political structure to the old one, etc.), but the insightful and profound reading allows singling out much more important features of modern era writing, which corresponds to the model of text with a clear postmodern trend (the syntheticism 


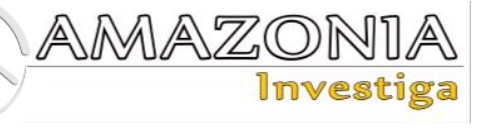

of a text, the elasticity of genre constructions, the combination of features of psychological and political novels, the essay-like character of the text), time and space displacements (the microcosm of certain individuals (Lukash Kyrylyshyn, Olesia Semyvus) is engulfed by the macrocosm of the whole nation, the accumulation and the expansion of important mental loci, etc.), the combination of real and unreal events, the virtualization of historicity, deep images-metaphors (Mamay, Virgin Mary), significant intertextuality, etc.).But the basic component permitting to put a bridge between romantic and postmodern writing in the novel is suffering and pain, which make possible this bizarre combination of the two literary movements.

\section{Methodology}

Research methods were selected in accordance with the problematics, poetics, literary and existential categories, that required a comprehensive methodological approach. The article is written with the historical-typological, psychoanalytic method and hermeneutic approach. Literary analysis of artistic work, which reveals important mental processes in Ukrainian society, involves the collection, systematization and generalization of material of cultural, philosophical, sociological content. Therefore, the historical-typological method is attached to decompose of the work of art in the process of interpretation, thanks to which the role of the revolution as a phenomenon of social discontent is analyzed. The historical-typological approach provided explanation and structuring of the typology of heroes and their psychology, revealed the importance for the Ukrainian nation of key aspects of the people's life - its identity, memory, historical justice, which correlate with historical and socio-political processes in the Ukraine. A full-fledged literary analysis of the text of S. Protsyuk's novel is served by certain aspects of psychoanalytic and existential approaches that provide interpretation of the behavior of characters, their dreams, mental and psychological atmosphere of character formation, crisis moments of their consciousness. Psychoanalytic and existential approaches have identified important tools for artistic modeling of the mental unconscious, which forces the characters to intensify rebellion and solve internal problems (tension, trauma, intimidation, harassment, pressure, archetypes of Mother and Mama, dreams and hallucinations, etc.). The hermeneutic approach involves the fullest interpretation of all levels and meanings of the text. An in-depth understanding of the text is facilitated by the analysis and systematization of signs, codes, text structures that explain and structure the meaning, idea, concept of the work.

\section{Results}

The category of suffering in the novel is multifaceted, it is interpreted by the author from a few standpoints: historical, mental, and personal. S. Protsiuk, basing on the artistic material, convinces of the necessity to return to the true historical past of Ukraine that will serve as a basis for resurrection of the national spirit with the purpose of reinterpretation of destructive processes of national oppression, ethnocide, linguicide, and culturicide, and formation of the preconditions for the national identity. The mental framework of suffering is represented by a distorted picture of the world that Ukrainians have, by deformed values and ideals, by disparaged categories of world-view. The deadly impact on the mental core of the nation, as the author convinces, was done mainly by the introduction of totalitarian regime, which programmed mental crises and mental traumas of the next generations of Ukrainians for a long time: "Suddenly Lukash understood that those twenty-something years were not enough for Ukraine to sweep communist sows and throw them out to a lay stall, they were not enough to burn off from our ill-starred land four damned letters - USSR" (Protsiuk, 2015b, p. 53).Finally, the historical and mental space of suffering logically continues the personal pain of the protagonist - Lukash Kyrylyshyn. Physical pain, provoked by renal failure, is emphasized by physical and moral suffering of the whole nation, manifested on Maidan. The individual physical discomfort of the character is entire and indivisible with the pain of the nation, which, through suffering, pain, and loss, is trying to obtain a chance for better / healthier life in free Ukraine, and then to largely reinterpret its national identity. The novel "Under the Wings of Big Mother" by S. Protsiuk unobtrusively continues the theme of the writer's previous work "Infection", in which the author only dots possible ways of overcoming infection / contamination of Ukraine, poisoned by soviet ideology. According to O. Pukhonska, "the novel "Under the Wings of Big Mother" by Stepan Protsiuk is a bright example of national consciousness reconstruction, of its evolution, of the way Ukrainians are making from colonial condition to freedom and establishment of their own selfhood" (p. 203). The novel by S. Protsiuk about Euromaidan proves the ability of the Ukrainian nation to eradicate totalitarian regime, post-soviet ideologies and soviet identity. 
Unfortunately, according to the novel of the Ukrainian writer, the similar process of reinterpretation and reformation is impossible without suffering and loss.

The novel "Under the Wings of Big Mother" by S. Protsiuk serves as a ground, on which one witnesses the development of the moral and ethical discourse of responsibility for the changes, produced by Maidan, in the life of certain characters and the nation in general. The revolution, according to S. Protsiuk, also produces a peculiar discourse of reckoning for excessive trustfulness, flattery and statist immaturity: "Lukash began to slowly understand that excessive hope for somebody's help is also the result of infantile national soul, its adolescent immaturity. But then it was necessary to mature not during long years of sluggish building up the state, but within days and hours. It was a compensation for the previous carefree and feeble twenty-two years of allegedly state building and its so-called sovereignty obtaining..." (Protsiuk, 2015b, p. 156). As it is proved in the novel, these state-forming drawbacks and inadvertences, as well as mental traps, should be accepted, reinterpreted and sober-mindedly analyzed while forming a strong national identity, which is extremely urgent and vital in the time of the revolution. According to P. Kostiuk, "delayed (slow, defective) national identification is one of the defining problems of nation's functioning" (p. 28), that is why the revolution became an important political and social moving force that accelerated the processes of state-building, finalizing the formation of mature national identity, awareness of the ethnic value and self-identity.

In the novel S. Protsiuk evaluates the key destructs in the process of state-building - quasiprofessionalism, bribery, corruption, mendacity of civil servants, indifference of progovernmental forces to the life of common people: "In the way there were standing fat bribetakers with a few bladders instead of one passionate heart, careful swineherds in livery and with forked tongues, with heads looking in different directions, artful intellectuals wearing ties, who support with words, but disappear when a pinch of sacrifice is needed" (Protsiuk, 2015b, p. 158).S. Protsiuk does not conceal psych destructs and drawbacks of Ukrainians in the process of national identity formation - laziness, indifference to social changes, amorality and passivity, servility and adulation, which impede the positive mechanism of national and personal identity formation. The author analyzes a number of psychological obstacles, mental traps and moral errors preventing from forming a national identity; they consist "in non-resistance to Holodomor", "in a black frog of envy", "in treasons, in scoffing at own language and own blood", "in commonplace self-devouring slyness", "in Makhno-like petty tyranny", "laziness, sentimentality, shallow 'sharovarshchyna', undereducation, and total pretentiousness" (Protsiuk, 2015b, p. 172).The formation of renewed mental discourse, declared by demands of Maidan, as it is proved in the novel by S. Protsiuk, is possible only through understanding of one's mental drawbacks and their relentless elimination.

Acts of resistance of the Ukrainian people in 2013 - 2014 had their causes and consequences, which are analyzed by S. Protsiuk in his novel "Under the Wings of Big Mother", and that makes the novel sound politically, blurring its psychological basis. Maidan resulted in important political and social changes, without which it is not possible to fully renew the mental core and change the course of national identity formation. The key point in ideological comprehension of the events of the Revolution of Dignity is the thesis of S. Protsiuk that goes like this: "Euromaidan is a mass surmounting of Ukrainian fear of death" (Protsiuk, 2015b, p. 24), bred by an inferiority complex and metal traumas, which were laid by imperial ideologies. Fear as a key category, which set in motion consciousness, feelings, and actions of Ukrainians on Maidan, is marked by a deep genetic trauma of ethnocide of the beginning of the $20^{\text {th }}$ century. Painful understanding and uttering of the traumatic experience of loss is necessary for Ukrainians in order never to permit a bloody scenario of $20 \mathrm{~s}-30 \mathrm{~s}$ of the $20^{\text {th }}$ century again. "Pestilence will begin. New 33 will come. At that time Ukrainian fields were covered with the starved to death, now they will be covered with the killed by fire. Rasputin's (they had different names, and this one - as well) will also get ready to the full annexation of Ukraine" (Protsiuk, 2015b, p. 165), observes S. Protsiuk in the novel, defining the reasons of emergence of total fear of conscious and patriotic Ukrainians. Therefore, the fear to repeat the historic past, to lose territorial integrity or even, maybe, to lose Ukraine entirely from the geopolitical maps, acquisition of new traumas, painful emotional experience, economic destabilization, and cultural crisis became the causes that prompted the beginning of the revolutionary movement. According to O. Pukhonska, "Ukrainian Revolution of Dignity marked the conclusive point of no return: on the one hand, it emphasized the difference between Ukrainian East and West, 


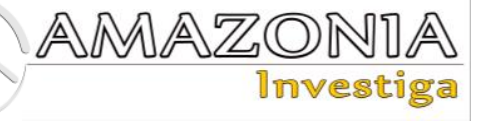

on the other hand, it revealed the reason of the national, cultural, and political crisis" (p. 207). Shameful anti-Ukrainian decrees that encroached on the territorial integrity of the country, its language, and true Ukrainian history, which are the basic identities (Lat. identitates) of the nation, provoked universal fear, based on the necessity of saving the nation and its identity. This fear demonstrated the relevance of regional and ethnic identities, which, as Liliia Khorishko and Natalia Horlo think, "grew with the simultaneous crisis transformation of the role of national identity. This problem was particularly acute in Central and Eastern Europe at the beginning of the 21 st century, when deepening integration into a single political and economic community raised fears among the political elite about its threat to national sovereignty and, consequently, to national identity" (p. 10).

Defenders of national dignity, consciousness, and identity were the youth, young students, who were standing at the origin of the bloody events, as their consciousness is the least wounded by mental traumas. Brought up as patriots, they were ready to fight, but they did not suspect that it would be so tragic: "Neither young men nor young women - nobody nowhere knew that the fight for the glory of the motherland would be mixed with the blood of a new pantheon of heroes, who, perhaps, had never dreamt before of deeds and had never suspected the existence of death that came to them, fiery and swift, in a radiant cope, in the heart of Ukrainian capital..." (Protsiuk, 2015b, p. 144).Students-protestors, Maidan supporters and the Heavenly Hundred became the first and the foremost adherents of the new philosophy of the national spirit and national identity. They were transformed into the symbolic images of the repressed death anxiety and of the true faith in a better future for Ukraine. Devoid of the desire of fame, only making proof of the invincible craving for freedom, they involuntarily formed a framework of the new revolutionary consciousness and history of conscious Ukrainians. "When they began to shoot, bullets were making heroes of yesterday's village fellows, who just wanted to live fairly (Protsiuk, 2015b, p. 164), notices S. Protsiuk in the novel. Fusilladed Heavenly Hundred, missing and wounded on Maidan, anxious crowd - all that bred an all-encompassing sorrow and the pain that prompted a substantial part of Ukrainians to rethink the mission of the victims and the price of casualties in the fight for a new Ukraine and the renewed national consciousness, brought by blood. "There were not more than a few dozen of Mamays, but apart from seven wounded and three killed, all were holding out.
Even the wounded were holding out. Even the killed ones did. There were no popoffs and cicerones. Charismatic leaders were gone as well. Maidan was filled only with the essence, without tops and lows" (Protsiuk, 2015b, p. 100), - notices S. Protsiuk, emphasizing the idea of Maidan, its mission in the further building up of Ukraine. The newly-formed national identity matured from overcoming of confusion, passivity, apathy to social changes, defenselessness, incertitude. It proved the ability of the nation to resist the neocolonial pressure.

The act of awakening of the national spirit and formation of a strong national identity was accompanied by the complicated, often invisible tectonic processes and events. In the novel the author also outlines a range of problems, which are secondary to the main theme of struggle. These are the problems of fake historical memory, of generation gap, of absence of fear as an instinct, of self-sacrifice in the name of Ukraine, of a thin line between a protest and a revolution, of shameful delinquency, of ways to achieve unity and solidarity of the nation. Apropos of this, M. Shor's opinion is quite correct: "Ukrainian revolution on Kyiv Maidan, despite its connection to a specific history, raised virtually universal questions of the nature of individuality, as well as problems of temporal flexibility and truth" (p. 19). The urgent problem of revision of the historic past, its utterance, no matter how painful it was, and, maybe, its reliving is a necessary act of getting rid of the shadow of soviets and mental traumas, which became one of the fundamental reasons of the Ukrainian Revolution.

It is well-known, that a national identity is a complex phenomenon deprived of statics that undergoes changes and transformations in every next generation through reinterpreting the events of the past. According to Liliia Khorishko and Natalia Horlo, "national identity should be equally formed both on a set of socio-cultural factors, namely language, history, culture, and on socio-economic factors, i.e. living standards and opportunities for self-realization" (p. 11).National identity formation is influenced by a few fundamental identitates (according to L. Greenfeld) - human beliefs, common historic past, active identity, long residence in the same country, common features (mentality, "national character") (p. 34). A complex process of formation of a mature national identity in the novel "Under the Wings of Big Mother" by $\mathrm{S}$. Protsiuk is accompanied by a revision of mental guidelines, that were systematically and regularly transgressed first and foremost in the 
soviet era. The title of the novel contains a subtitle "Mental Maidan" that has a double semantic message: on the one hand, it logically continues and emphasizes the metaphoric title "Under the Wings of Big Mother", explaining the key Ukrainian codes and symbols; on the other hand, it adds new meanings to the genre contaminations of the novel. On this occasion it is worth paying attention to the comment of the author, who noticed that that work was "an attempt of a novel about waiting for shifts of Ukrainian mentality, and Maidan is their allegory" (Protsiuk, 2015a). Apparently, S. Protsiuk purposed to define a fundamental element in the national identity formation mentality.

According to L. Nagorna, "the mentality of a nation is manifested in the peculiarities of worldview, predominant social frames of mind, life strategies, in the system of values and moral norms, in labor ethics and treatment of the environment, in family ties and upbringing principles. It is manifested to the fullest extent in the national character, cultural and symbolic forms of the national identity, national psychology, ethno-religious traditions, etc. It serves as a ground for the feeling of identity, on its basis a code of rules defining political and everyday behavior of individuals is formed" (p. 23-24). The change of the geopolitical status of the country after obtaining independence did not bring about essential improvements in its mental background, which still continued being defined through the ideologemes of the soviet institutions. Thus, an attempt to bring Ukrainians back to the soviet system, destruction of healthy values and moral guidelines, violation of labor ethics, neglect of important national symbols and codes, neglect of language - all that made a framework for the future revolution of changes.

The encroachment of pro-governmental political structures with a distinct pro-soviet position upon a typically Ukrainian mentality provoked social dissatisfaction and indignation, and thereafter mass resistance. P. Kostiuk, while analyzing the origins of confrontation between Ukrainian mentality and the so-called "Russian world", noticed: "Blurring of Ukrainian mentality and traditional values, an attack against language, culture, system of education, historical memory of the people, even national churches serve the same purpose - to destroy the identity of Ukrainian nation. As we know, the identity of any nation makes a basis of the national security and, subsequently, of the powerful national state - Ukraine” (p. 29). Disparagement of historical past, faking of historical memory, neglect of language and national traditions during the rule of the president Yanukovych and "The Party of the Regions" caused mass indignation, since it potentially declared destruction and demolition of basic for Ukrainians mental foundations. In fact, this pro-government structure has formed the phenomenon of separatism in Ukraine, which, on opinion S. Gusarov, O. Zolotar, M. Belanuk, "as a phenomenon has deep historical roots, which is related to the existence of contradictions between the historical traditions of the interaction of states on the principles of state sovereignty and inviolability of borders on the one hand, and the principle of the right of nations to selfdetermination, established in the practice of international relations providing the possibility to form independent states", so as it was clarified by authors "is one of the most acute threats to the national and political security of the country" (pp. 30-34). Then political elite strikingly opposed itself to the Ukrainian people, by all means demonstrating its difference and separation, distinct basic mental categories. We find correct the opinion of M. Yuriy: "remaining invisible for its bearers, the mentality is comprehended particularly acutely, when they have to interact with the bearers of a different mentality" (p. 588), which justifies the activity of Maidan, unable to put up with the established political system.

World-view, world-attitude, self-positioning, belonging to a certain nation, collective memory, community of national interests make a background for further development and consolidation of the national identity either of the ethnicity in general or of an individual in particular. The process of obtaining national identity is complicated and dynamic; it is subject of changes, crises and traumas. Apropos of this, O. Gnatyuk notices: "Identity - not only individual, but also collective, including national identity - is not static. It changes, and these changes appear as a result of reinterpretation" (p. 13). In the novel "Under the Wings of Big Mother" reinterpretation and revision were needed for the discourse of the so-called Mordor, an allusion to Tolkien's Black Land, translated from Old English as enemy, - soviet and neocolonial structure, a usurper of Ukraine, a translator of imperial doctrines. Mordor is a metaphor of nation's mental death, its demoralization, and dispiriting. In the mental aspect Mordor is seen as continuation of the soviet ideology and imperial conception of Ukraine's destruction. "Over there Mordor will creep into every crack of our steppes and mountains, killing and poisoning every living 


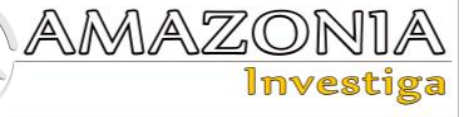

creature. Hopes for freedom will vanish, at every step agent will appear, agents, ready to send all the dissidents to a dungeon; SBU will become SBR (Security Service of Russia), Russian battalions will be gadding in the streets; battalions that killed the old and the pregnant in Chechnya, leaving no stone unturned" (Protsiuk, 2015 b, p. 53), states' S. Protsiuk in the novel. Apparently, the policy of Mordor, as seen by Lukash Kyrylyshyn, disorganizes the state regime of Ukraine, undermining the fundamentals of statist thinking, depriving it of its mental origins, national foundations and ethical and moral responsibility. Destructive imperatives of Mordor impose a complex of Little Russians, an inferiority complex on unctuous and unstable Ukrainians, programming them to be consistent, smooth-tongued, and complaisant.

The consciousness of Lukash Kyrylyshyn - a deliberate Ukrainian patriot - constantly modeled imaginary situations of "mordoring" of Ukraine; situations that serve as an evidence of prolonged fear of being found under the regime of the former colonizer: "Your Ukraine does not exist anymore, it will never exist, shit! right sector, Hitler kaput! There is no your stupid dialect and your damn speech of Galicia and Volyn, of Cherkasy and Kyiv! There is no your trident and your flag - your signs of Lucifer! We, a great messianic army, have trampled on all of that, we have burned it on the sacred bonfires in the name of Rus, which we, son of a bitch, will resuscitate on your bandera's lands" (Protsiuk, 2015 b, p. 25). It must be noted that the author emphasizes the important national, spiritual, and cultural identities of the independence period consolidating the nation - language, national symbols (a coat of arms and a flag), Western lands as a stronghold of Ukrainian identity and state hood. National and sacred discourse of Ukraine is accentuated in S. Protsiuk's novel through other expressive images-metaphors Mamays and Virgin Mary, the image of suffering and many-sided Ukraine, which together with the language, the territory, the coat of arms, the flag and the anthem make a strong framework for further building up of the national identity. Ideological expressivity of Ukrainian Maidan is achieved through the emotionality of loss and regeneration, hope for the free future of Ukraine.

The tragic events of the Revolution of Dignity favored the transformation of a crowd into a consolidated nation, which, having united, showed its national striving for liberty, free will expression, and cordiality. The Ukrainian people declared its dignity and rebellion. "One wanted to be dissolved in this crowd, to merge with its sorrow. One wanted to fall down on the sacred square kissing the spilled blood of the Heavenly Hundred that was invisibly spreading about entire Ukraine, was leaking into the bureaucrats' offices distorting and wrenching officious clumsy bodies in soft armchairs. Mothers' tears and knights' blood were building the foundation wall of the new country" (Protsiuk, 2015b, p. 158). The price of numerous bereavements was paid for the new national identity, for the strengthened mentality, and for the hardened national character.

\section{Conclusions}

Thus, the novel "Under the Wings of Big Mother" by S. Protsiuk harmoniously enters into the discourse of revolutionary and military literature of the beginning of the $21^{\text {st }}$ century actualizing important for the Ukrainian people questions of national identity, mentality, traumatization, and consolidation of Ukrainians. The formation of a new national identity of Ukrainians, provoked by the events of the Revolution of Dignity, is conditioned by the discourse of suffering, pain, and sorrow that consolidated and mobilized the nation to defend mental foundations; it is also stipulated by the understanding of Ukraine's past traumatic experience - genocide, linguicide, culturicide's formation of the new Ukrainian identity was also favored by critical comprehension of drawbacks and mistakes in Ukrainians' world-attitude and world-image, marked by the inferiority complex, "sharovarshchyna", as well as servility, pretentiousness, passivity, and undereducation. The revision of soviet values and categories provoked an emergence of a different national identity destined to strip Ukrainians of their inferiority complex, passivity, diffidence, colonial mentality. The fear to repeat political repressions and to lose the integrity of Ukraine, bilingualism, desacralization of important symbols and codes in the mental core of the nation expressively declared the necessity to form a new national identity. The novel "Under the Wings of Big Mother" by S. Protsiukraises other important problems of the national discourse development. These are the problems of historical memory, colonialism / anticolonialism, patriotism, ethnocentrism, which make the prospect of the further scientific research.

\section{Bibliographic references}

Gnatyuk, O. (2005). Farewell to the Empire. Kyiv: Criticism. [in Ukrainian]. 
http://history.org.ua/LiberUA/966-7679-799/966-7679-79-9.pdf

Greenfeld, L. (1994). Nationalism: Five Roads of Modernity. History and Theory, 33(1), 34-36.

https://www.hup.harvard.edu/catalog.php?is bn=9780674603196

Gusarov, S., Zolotar, O., Belanuk, M., \& Svyrydova, L. (2020). Legal Principles of Opposition to Separatism in the Modern State. Amazonia Investiga, 9(29), 29-36. https://doi.org/10.34069/AI/2020.29.05.4

Khorishko, L., \& Horlo, N. (2021). National identity in the discourse of political elites of Poland and Hungary. Amazonia Investiga, 10(40), 9-16. https://doi.org/10.34069/AI/2021.40.04.1

Kostyuk, P. (2018). The Code of Identity. Lviv: Universe. [in Ukrainian]

Nagorna, L. (2002). National Identity in Ukraine. Kyiv: IPED. [in Ukrainian]
Protsiuk, S. (2015a). I Choose the Laws of Heart. [Interview by Natalia Tkachik]. Galician correspondent, April 25. Retrieved from:http://gk-press.if.ua/x20724/[in Ukrainian]

Protsiuk, S. (2015b). Under the Wings of Big Mother. Mental Maidan. Brusturiv: Discursus. [in Ukrainian]

Pukhonska, O. (2016). Euromaidan as a Challenge to the Post-totalitarian Memory (based on the novel "Under the wings of big Mother" by S. Protsiuk)". Bulletin of V.O. Sukhomlynskyi MNU. Philological sciences (literary criticism), 17(1.203-208). [in Ukrainian]

Shore, M. (2018). Ukrainian Night. History of Revolution Seen From Near. Kyiv: Duh I Litera. [ in Ukrainian]

Yuriy, M. (2008). Socio-cultural World of Ukraine. Kyiv: Kondor 38. [in Ukrainian] 